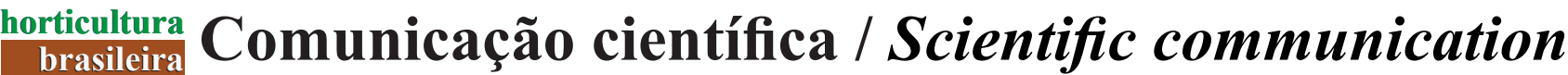

PRATISSOLI D; LIMA VLS; PIROVANI VD; LIMA WL. 2015. Occurrence of Helicoverpa armigera (Lepidoptera: Noctuidae) on tomato in the Espírito Santo state. Horticultura Brasileira 33: 101-105. DOI - http://dx.doi.org/10.1590/S0102-053620150000100016

\section{Occurrence of Helicoverpa armigera (Lepidoptera: Noctuidae) on tomato in the Espírito Santo state}

\author{
Dirceu Pratissoli'; Victor LS Lima²; Victor D Pirovani ${ }^{3}$; Wallace L Lima ${ }^{2}$ \\ ${ }^{1}$ UFES-CCA, C. Postal 16, 29500-000 Alegre-ES; dirceu.pratissoli@ufes.br; ${ }^{2}$ IFES, C. Postal 47, 29500-000 Alegre-ES; victor. \\ souzalima@gmail.com; wallace@ifes.edu.br; ${ }^{3}$ IFMG, S.J. Evangelista, 39705-000 São João Evangelista-MG; victorpirovani@gmail.com
}

\begin{abstract}
The species Helicoverpa armigera is one of the most important polyphagous and widely distributed pests in the world. Its occurrence was recently reported on soybean and cotton, in the states of Goiás, Mato Grosso and Bahia, Brazil. Tomato is also host species of $H$. armigera, among the 200 registered, being one of the most important crops in the Espírito Santo state. The production of tomatoes is fully dedicated for fresh consumption and the damage caused by $H$. armigera in fruits make unfeasible marketing. Therefore, this study aimed to record the occurrence of $H$. armigera in tomato crop in the Espírito Santo state. From February 2012 to October 2013, insects were collected from tomato plants in some producing areas. After insect identification, by dissection of the genitalia of adult moths, it was possible to confirm the occurrence of $H$. armigera on tomato crop in the Espírito Santo state.
\end{abstract}

Keywords: Solanum lycopersicum; Heliothinae; moth; caterpillar.

\section{RESUMO}

Ocorrência de Helicoverpa armigera (Lepidoptera: Noctuidae) em tomateiro no estado do Espírito Santo

A espécie Helicoverpa armigera é uma das mais importantes pragas polífagas e de ampla distribuição geográfica. Recentemente, foi registrada sua ocorrência no Brasil, nos estados de Goiás, Bahia e Mato Grosso nas culturas de soja e algodão. O tomateiro também é espécie hospedeira de $H$. armigera, entre as 200 espécies registradas, sendo uma das culturas mais importantes no estado do Espírito Santo. A produção de tomates é totalmente voltada para consumo in natura e os danos causados por $H$. armigera nos frutos inviabilizam a sua comercialização. Esse trabalho teve como objetivo registrar a ocorrência de $H$. armigera na cultura do tomate no estado do Espírito Santo. No período de fevereiro de 2012 a outubro de 2013 foram realizadas coletas de insetos atacando plantas de tomateiro nas regiões produtoras no estado. Após a identificação por meio da dissecação da genitália das mariposas adultas, ficou comprovada a ocorrência de H. armigera em cultivos de tomate no Espírito Santo.

Palavras-chave: Solanum lycopersicum, Heliothinae, mariposas, lagartas.

\section{(Recebido para para publicação em 10 de março de 2014; aceito em 16 de outubro de 2014)} (Received on March 10, 2014; accepted on October 16, 2014)

$\mathrm{T}^{\mathrm{s}}$ he species Helicoverpa armigera (Lepidoptera: Noctuidae) is one of the most important polyphagous pests in agriculture. This species attacks over 200 plant species worldwide, having been reported in Europe, Asia, Africa and Oceania (Zalucki et al., 1986, 1994; Guo, 1997). In Brazil, this pest was considered quarantine by early 2013, when a confirmation of its occurrence in soybean (Glycine max) and cotton (Gossypium hirsutum) and in soybean plants infesting other crops (seeds remaining from previous crops) was observed in the states of Goiás, Mato Grosso and Bahia, respectively (Czepak et al., 2013).

Helicoverpa armigera causes severe losses in different plant species, especially cotton, sorghum, beans, soybeans, canola, corn and tomato (Fitt, 1989; Romeis \& Shanower, 1996; Pogue, 2004; Moral Garcia, 2006).The female moths lay around 1000-1500 eggs, singly, on leaves, flowers, fruits and stalks, which makes clear their reproductive potential (Fye \& McAda, 1972). Helicoverpa armigera caterpillar can damage both the vegetative phase as the reproductive phase of the plant, feeding on leaves, stems, buds, inflorescences, fruits and pods (Reed, 1965; Wang \& Li, 1984). Direct damage to the structures of flowering and fruiting of host plants by $H$. armigera caterpillars and the extensive use of insecticides result in low productivity and high costs of control, respectively (Lammers \& MacLeod, 2007; Fathipour \& Naseri, 2011).

This work aims to report the occurrence of $H$. armigera in tomato crop in Espírito Santo state, considering constant requests for inspections in tomato crops attacked by caterpillars.

\section{MATERIAL AND METHODS}

From February 2012 to October 2013, outbreak occurrences were reported and collections of caterpillar populations were carried out on tomato crop as well as evaluation of types 
of injuries in plants and fruits and identification of the sampled species.

Collections were carried out in the three main production centers of tomato for fresh consumption in Espírito Santo state, those sampled regions being responsible for $82 \%$ of the production (Borel et al., 2010). The first pole is located in the municipality of Venda Nova do Imigrante (São José do Alto Viçosa District, 20²3'56"S, $41^{\circ} 06^{\prime} 44^{\prime}$ 'W), the second pole comprises the municipality of Afonso Claudio (Rio da Cobra, Fazenda Guandu, 2013'05'S, 41 ${ }^{\circ} 06^{\prime} 02^{\prime}$ 'W), and the third pole is the municipality of Guaçuí (Rod. Guaçuí/Varre-Sai, 2049'53' S, 41 42'54' W) (Figure $1)$. Besides the production centers, collections in tomato fields, at the Instituto Federal de Educação do Espírito Santo, were carried out, in the municipality of Alegre (Rive District, $\left.20^{\circ} 45^{\prime} 54^{\prime \prime} \mathrm{S}, 41^{\circ} 27^{\prime} 27^{\prime \prime} \mathrm{W}\right)$ (Figure 1). Monthly samplings were carried out, at the stages of vegetative development and production of tomato, in three fields from each of the four selected regions for the work. The tomato cultivars grown in the fields were: Alambra, Fusion, Ivanhoé, Sophia and Batalha.

Collections were made at random, walking between the lines of planting to find fruits with holes up to $1 \mathrm{~cm}$ in diameter, which could be related to $H$. armigera or to the corn earworm on tomato Helicoverpa zea (Lepidoptera: Noctuidae), also called "brocão" (large caterpillar) by the producers. The damaged fruits were placed, individually, in plastic containers (12 $\mathrm{cm}$ diameter $\mathrm{x} 8 \mathrm{~cm}$ height) and sent to Setor de Entomologia do Núcleo de Desenvolvimento Científico e Tecnológico em Manejo de Pragas e Doenças of Universidade Federal do Espírito Santo. In the laboratory, the fruits were carefully cut, using a knife, to remove the caterpillars that might be inside.

All specimens were collected in the larval stage and placed in plastic boxes $(11 \times 11 \times 3.5 \mathrm{~cm})$ in order to avoid cannibalism among the larvae. The boxes with the specimens collected were stored at a climate-controlled room at a temperature of $25 \pm 2^{\circ} \mathrm{C}$, relative humidity of $70 \pm 10 \%$ and photophase of 12 hours. The caterpillars were fed until the pre-pupal phase with immature fruits of tomato (approximately $5 \mathrm{~cm}$ diameter). When reaching the pupal stage, the caterpillars were grouped in a cage consisted of an acrylic box $(50 \times 50 \times 50 \mathrm{~cm})$. When adults emerged, a part was captured and killed by freezing in a freezer at $-10^{\circ} \mathrm{C}$ for 30 minutes. Later, the adults were mounted with entomological pins and sent to a specialist at Embrapa Cerrados, Brasília, Dr. Alexandre Specht, in order to perform the morphological characterization. The identification of specimens was performed through dissection and morphological analysis of the genitalia of male individuals (Specht et al., 2013).

\section{RESULTS AND DISCUSSION}

In all crops of municipalities of Venda
Nova do Imigrante, Afonso Claudio, Guaçuí and Alegre, the occurrence of $H$. armigera was observed. These municipalities are the main tomato producers and they are located in the South Central region of Espírito Santo state.

Evaluating probable injuries caused by $H$. armigera, we observed that the injuries were on the fruits, except for one plant, which was attacked on the stem, where the formation of galleries $(4 \times 1 \mathrm{~cm})$, downward, starting near the apical bud, was noticed. The attacked fruits were in medium to advanced developmental stage and were about $4 \mathrm{~cm}$ in diameter. The lesions showed varied shape, as a simple hole in the pericarp to the partial destruction of the fruits reaching the endocarp (Figure 2). The caterpillars which were causing lesions were more than $2 \mathrm{~cm}$ in length and showed varied pattern of colors from pale green to dark gray. With respect to the behavioral aspect, we observed that

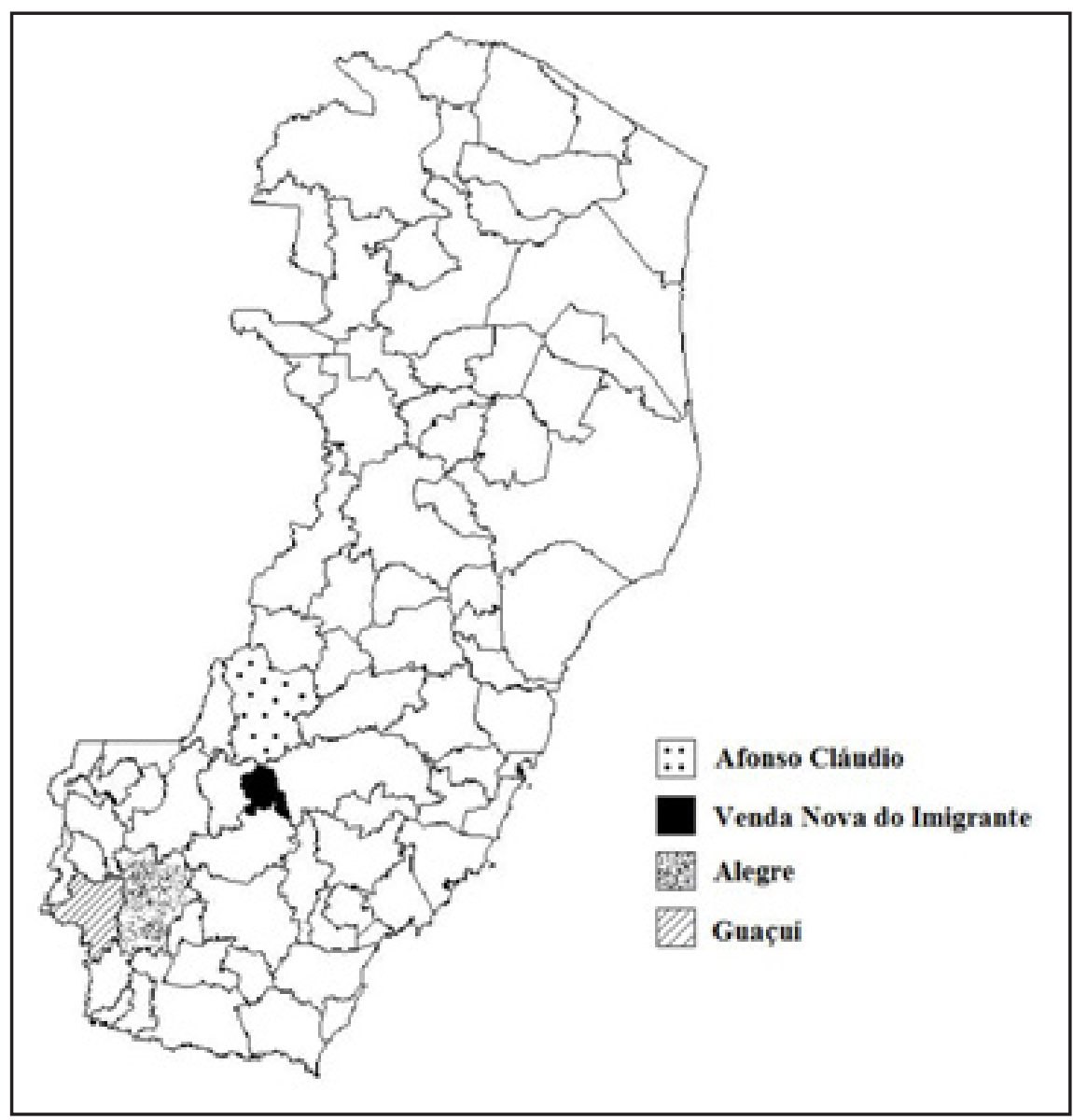

Figure 1. Municipalities in the state of Espírito Santo where samplings of Helicoverpa armigera were conducted (municípios do estado do Espírito Santo onde foram realizadas coletas de Helicoverpa armigera). Alegre, UFES, 2014. 


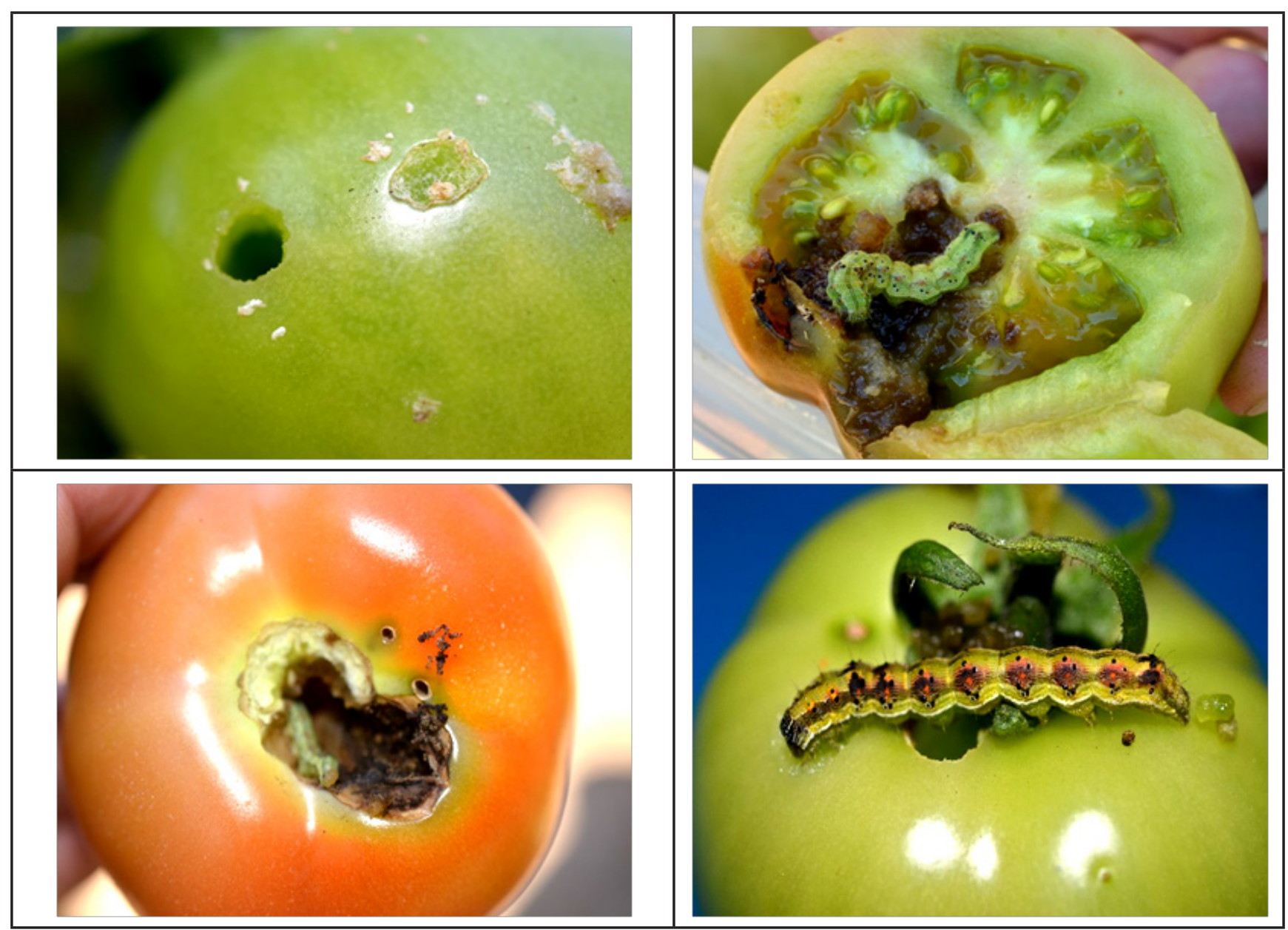

Figure 2. Injuries caused by Helicoverpa armigera caterpillar in tomato fruit in the Espírito Santo state (injúrias causadas por lagartas de Helicoverpa armigera em frutos de tomate no estado do Espírito Santo). Alegre, UFES, 2014.

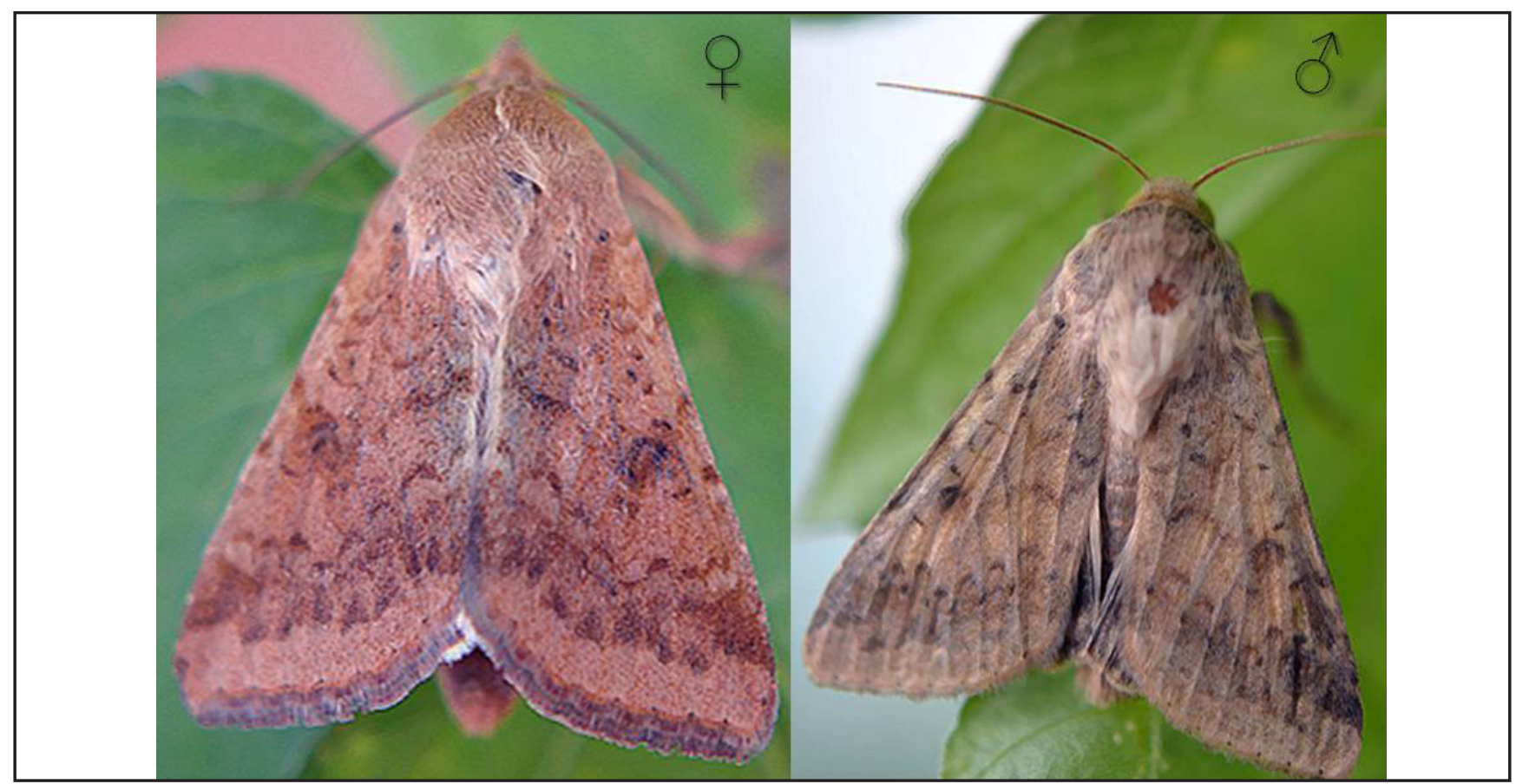

Figure 3. Female (left) and male (right) adult moth of Helicoverpa armigera \{mariposas adultas fêmea (esquerda) e macho (direita) de Helicoverpa armigera\}. Alegre, UFES, 2014. 
caterpillars remained on or in the lesions during daytime, this behavior is different from the corn earworm in tomato, which seeks the fruits only at night.

The species $H$. armigera is similar to other caterpillar species like H. zea, Heliothis virescens and Helicoverpa gelotopoeon. All of them belong to the family Noctuidae and subfamily Heliothinae and, therefore, they share some morphological characteristics. The caterpillar staining pattern is variable, according to the food (host plant) they eat, environmental conditions and age of larvae (Ali \& Choudhury, 2009). The adult moths also have great similarity, mainly related to the size $(35-45 \mathrm{~mm}$ wingspan) and the color of the wings, which varies from light yellow to dark brown (EPPO, 1981, 1996). However, other characteristics can help identify $H$. armigera, as the format of "saddle" on the first abdominal segment from the fourth instar and the behavior of bending the head capsule toward the first pair of false legs when touched (Matthews, 1999). Adults of $H$. armigera present sexual dimorphism. The females have the first pair of wings of brown orange color whereas the males have their first pair of wings of greenish gray color (Czepak et al., 2013) (Figure 3). Although some characteristics assist in identification of $H$. armigera, the morphological characterization, through dissection of the genitalia or molecular tools, is indispensable in order to state the species (Pogue, 2004; Tay et al., 2013).

The introduction of $H$. armigera in Brazil creates another problem, besides its difficult identification, that is the pest management. The difficulties in this pest management are faced in countries from different continents such as Europe, Asia, Africa and Oceania (Tayet al., 2013). In Australia, for instance, despite the experience in combating $H$. armigera, management programs of pest resistance to insecticides have identified high levels of resistance, which reduces the effectiveness of most chemical groups employed in its management (Fitt \& Wilson, 2000).

In tomato crops in Espírito Santo state, the pest management relies on the use of insecticides of diamides groups and products based on Baculovirus and Bacillus thuringiensis (Bt). However, other methods can be employed in $H$. armigera management, in tomato and in other host crops of this species (Fathipour \& Sedaratian, 2013).The use of egg parasitoids of the genus Trichogramma (Oztemiz et al., 2009), entomopathogenic nematodes (Hussain et al., 2014) and sex pheromones (Malik et al., 2003) are strategies of biological control with potential to be used in the management of $H$. armigera, considering the easiness that this species can develop resistance to certain insecticides (Fitt \& Wilson, 2000).

The presence of $H$. armigera on tomato production in Espírito Santo state is already causing productivity losses and conducting surveys in other host crops for monitoring this species in the state is necessary. Due to the observation of the occurrence of $H$. armigera, work for providing awareness and orientation on the pest capacity of developing resistance have been carried out with producers, including the training of professionals for the proper identification and management of this exotic pest in Espírito Santo state.

\section{ACKNOWLEDGEMENTS}

To Fundação de Amparo à Pesquisa no Espírito Santo (Foundation for research support of Espírito Santo, FAPES) and to the Conselho Nacional de Desenvolvimento Científico e Tecnológico (National Council for Scientific and Technological Development, CNPq) for financial support to NUDEMAFI projects; to Dr. Alexandre Specht, for the identification of $H$. armigera, and to the technical consultant at COOPEAVE, Edson Cozer, for the support in field sampling.

\section{REFERENCES}

ALI A; CHOUdHURY RA. 2009. Some biological characteristics of Helicoverpa armigera on chickpea. Tunisian Journal of Plant Protection 4: 99-106.

BOREL RMA; ABAURRE MEO; CARMO CAS. 2010. Características socioeconômicas do cultivo do tomateiro no estado do Espírito
Santo. In: Tomate.Vitória-ES: Incaper. p.69-84. CZEPAK C; ALBERNAZ KC; VIVAN LM; GUIMARÃES HO; CARVALHAIS T. 2013. Primeiro registro de ocorrência de Helicoverpa armigera (Lepidoptera: Noctuidae) no Brasil. Pesquisa Agropecuária Tropical 43: 110-113. DOI: $10.1590 / \mathrm{S} 198340632013000100015$.

EPPO. 1981. Data sheets on quarantine organisms no. 110: Helicoverpa armigera. Paris: EPPO. (Bulletin, 11).

EPPO. 1996. Helicoverpa zea. In: SMITH IM et al. (eds). Quarantine pests for Europe. 2. ed. Wallingford: CAB International. p.1-6.

FATHIPOUR Y; NASERI B. 2011. Soybean cultivars affecting performance of Helicoverpaarmigera (Lepidoptera: Noctuidae). In: Ng TB. (ed) SoybeanBiochemistry, Chemistry and Physiology. Rijeka: InTech. p.599-630.

FATHIPOUR Y; SEDARATIAN A. 2013. Integrated management of Helicoverpa armigera in soybean cropping systems. In: ELSHEMY HA (ed). Soybean - pest resistance. Cairo: InTeOpP. p.231-280.

FITT GP. 1989. The ecology of Heliothis species in relation to agroecosystems. Annual Review of Entomology 34: 17-52.

FITT GP; WILSON LJ. 2000. Genetic engineering in IPM: Bt cotton, in: KENNEDY GG; SUTTON TB (eds) Emerging Technologies in Integrated Pest Management: Concepts, Research and Implementation. APS Press: St Paul, USA. p.108-125.

FYE RE; Mc ADA WC. 1972. Laboratory studies on the development, longevity and fecundity of six lepidopter on pests of cotton in Arizona, USDA. Res. Serv. Tech. Bull 1454: 72.

GUO YY. 1997. Progress in the researches on migration regularity of Helicoverpa armigera and relationships between the pest and its host plants. Acta Entomologica Sinica 40: 1-6.

HUSSAIN MA; AHMAD R; AHMAD W. 2014. Evaluation of Steinernema masoodi (Rhabditida: Steinernematidae) against soildwelling life stage of Helicoverpa armigera (Lepidoptera: Noctuidae) in laboratory and microplot study. Canadian Journal of Plant Protection 2: 4-8.

LAMMERS JW; MACLEOD A. 2007. Report of a pest risk analysis: Helicoverpa armigera (Hübner, 1808). Disponível em: http:// www.fera.defra.gov.uk/plants/ plantHealth/ pestsDiseases/documents/helicoverpa.pdf. Acessado em: 08 de novembro de 2013.

MALIK MF; HUSSAINY SW; RAHMAN DU; MUNIR A; ALI L. 2003. Efficacy of synthetic pheromone for the control of Helicoverpa armigera in Tomato. Asian Journal of Plant Sciences 2: 415-417.

MATTHEWS M. 1999.Heliothinae moths of Australia: a guide to pest bollworms and related noctuid groups. Melbourne: CSIRO. 320 p.

MORAL GARCIA FJ. 2006. Analysis of the spatio temporal distribution of Helicoverpa armigera (Hübner) in a tomato field using a stochastic approach. Biosystems Engineering 93: 253-259.

OZTEMIZ S; KARACAOGLU M; YARPUZLU 
F. 2009. Parasitization rate of Helicoverpa armigera Hübner (Lepidoptera: Noctuidae) eggs after field releases of Trichogramma evanescens westwood (Hymenoptera: Trichogrammatidae) in cotton in Cukurova region of Turkey. Journal of the Kansas Entomological Society 82: 183-193.

POGUE MG. 2004. A new synonym of Helicoverpa zea (Boddie) and differentiation of adult males of $H$. zea and $H$. armigera (Hübner) (Lepidoptera: Noctuidae: Heliothinae). Annals of the Entomological Society of America 97: 1222-1226.

REED W. 1965. Heliothis armigera (Hb.) (Noctuidae) in western Tanganyika: II. Ecology and natural and chemical control. Bulletin of Entomological Research 56:
127-140.

ROMEIS J; SHANOWER TG. 1996. Arthropod natural enemies of Helicoverpa armigera (Hbn.) in India. Biocontrol Sci. Techn 6: 481-508.

SPECHT A; SOSA-GÓMEZ DR; PAULAMORAES SV; YANO SAC. 2013. Morphological and molecular identification of Helicoverpa armigera (Lepidoptera: Noctuidae) and expansion of its occurrence record in Brazil. Pesquisa Agropecuária Brasileira 48: 689-692.

TAY WT; SORIA MF; WALSH T; THOMAZONI D; SILVIE P; BEHERE GT; ANDERSON C; DOWNES S. 2013. A brave new world for an old world pest: Helicoverpa armigera (Lepidoptera: Noctuidae) in Brazil. PLoS ONE 8: e80134. doi:10.1371/journal.pone.0080134
WANG NC; LI ZH. 1984. Studies on the biology of cotton bollworm (Heliothis armigera Hübner) and tobacco budworm (Heliothis assulta Quenee). Journal of the Shandong Agricultural University 1-2: 13-25.

ZALUCKI MP; DAGLISH G; FIREMPONG S; TWINE PH. 1986. The biology and ecology of Heliothis armigera (Hübner) and $H$. punctigera Wallengren (Lepidoptera: Noctuidae) in Australia: what do we know? Australian Journal of Zoology 34:779-814.

ZALUCKI MP; MURRAY DAH; GREGG PC; FITT GP; TWINE PH; JONES C. 1994. Ecology of Helicoverpa armigera (Hübner) and $H$. punctigera (Wallengren) in the inland of Australia: larval sampling and host plant relationships during winter and spring. Australian Journal of Zoology 42:329-346. 